\title{
Lessons for African Economies from Irish and East Asian Industrial Policy
}

\author{
David Bailey, Helena Lenihan ${ }^{1}$ and Ajit Singh ${ }^{2}$
}

Abstract When comparisons in terms of industrial policy lessons to be learned have taken place, it has tended to be solely vis-a-vis the 'development state' East Asian experience. This paper broadens the analysis and considers lessons which African countries can learn from other so-called 'tiger' economies including Ireland and the East and South Asian countries. We recognise that the latter are indeed clearly significant as many African countries at the time of independence had economic structures and levels of income quite similar to East Asian countries, yet have grown at vastly different rates since then. Exploring why this has been the case can thus offer important insights into possibilities for industrial policy. Yet this comes with some health warnings over East Asian experience. We suggest that another important contribution can come by looking at the Irish example, given its emphasis on corporatism rather than simply relying on state direction in the operation of industrial policy. The Irish model is also more democratic in some senses and has protected workers' rights during the development process in contrast to the often highly dirigisite East Asian model. Overall we suggest that some immediate actions are needed, notably with regard to the financial system in small African economies. Without such changes, a poorly functioning financial system will continue to keep investment at low levels. In relation to the small size of the African economies, the paper recommends regional integration and sufficient overseas development assistance (ODA) for infrastructural development. It is also critical to note that the various small African economies each face their own industrial and economic development challenges, and that a 'one size fits all' approach is not appropriate; rather the key is to tailor policies and systems to the unique opportunities and development challenges in each African country.

Keywords: Industrial Policy; Ireland; East Aisa; Economic Development; FDI; Small firms.

JEL Classification F23, L52, L53, O2, P16

\footnotetext{
${ }^{1}$ Corresponding Author. Email: helena.lenihan@ul.ie tel: + 35361202079 Address: Department of Economics, Kemmy Business School, University of Limerick, Limerick, Ireland.

${ }^{2}$ Bailey is Professor of International Business Economics and Strategy at Coventry University Business School, UK. Lenihan is based at the Department of Economics, Kemmy Business School, University of Limerick, Ireland. She worked on this paper during her sabbatical leave as a Visiting Fellow at the CBR at Judge Business School, University of Cambridge and concurrently a Visiting Fellow at Wolfson College, University of Cambridge UK and finally as a visiting academic at the CSME, Warwick Business School, University of Warwick, UK. Singh is Emeritus Professor of Economics, University of Cambridge and Director of Research with CERF at the Judge Business School in Cambridge, UK. He is also a Professor of Economics at the Birmingham Business School, UK.
} 


\section{Introduction}

African economies, particularly in Sub-Saharan Africa (SSA) stand at an important juncture. During the 1980s, for the average African country, GDP per capita actually fell at a rate of 0.5 percent per annum; in the 1990s it rose slightly at a rate of 0.3 percent per annum (see Table 1 below). However, in the last four years, the average growth rate has been a respectable 3 percent per annum. In 2007, GDP growth rate in Africa was estimated to be 6 percent per annum, one of the highest rates recorded during any year over the last quarter century. Apart from indicating the recent recovery in African economic growth, the table also highlights the poor long term performance of the African economies relative to other developing countries. Over the entire 26 year period, 1981-2007, as seen in Table 1, per capita GDP in African countries rose only by 16 percent compared with more than a 100 percent rise for all developing countries. In contrast, for the East and South Asian economies, the growth in GDP per capita has been spectacular, a rise of well over 300 percent.

Table 1: PER CAPITA GDP GROWTH BY REGION AND ECONOMIC GROUPING, 1981-2007

(Per Cent)

$\begin{array}{ll}\text { Average annual } & \text { Overall } \\ \text { Growth } & \text { growth }\end{array}$

\begin{tabular}{lcccc}
\hline & \multicolumn{1}{c}{$\begin{array}{l}1981- \\
1999-\end{array}$} & 2002 & $\begin{array}{c}2003- \\
2007\end{array}$ & $\begin{array}{l}1981- \\
2007\end{array}$ \\
\hline World & 1.4 & 1.2 & 2.3 & 41.4 \\
Developed economies & 2.5 & 1.8 & 2.08 & 67.5 \\
Economies in transition & 1.9 & -4.0 & 7.3 & -25.8 \\
$\begin{array}{l}\text { Developing economies } \\
\text { Of which: }\end{array}$ & 1.7 & 3.0 & 5.0 & 112.5 \\
\multicolumn{1}{c}{ Africa } & -0.5 & 0.3 & 3.0 & 16.4
\end{tabular}


America

Source: UNCTAD (2007A).

It is a moot point whether this recent reversal of fortunes for the African countries has been due to the late success of structural adjustment programmes (SAPs) of the World Bank and the IMF, as is claimed by the two Bretton Woods institutions (World Bank, 2007; IMF, 2008). These programmes, which have been the dominant influences on Sub Saharan African economies during much of 1980 s and all of 1990s have embodied the Washington Consensus and its aftermath. According to independent economists [UNCTAD (2005), and (2007A), ILO (2007), Mickenley (2005), and Lall (2005)], although many countries implemented these programmes, there has not actually been much success in enhancing their economic growth on a sustained basis. Indeed Mkandawire (2005), a leading scholar of African economies, argues that the SAPs were essentially counterproductive and in fact often led to the wrong kind of structural change which hindered rather than helped economic development.

Rather, the most plausible reason for the fast growth of African economies in the last four years would instead appear to be the huge increase in international commodity prices. Information provided by UNCTAD (2007A), as seen in table 2 below, reveals how the prices of various commodities have changed over this period:

\begin{tabular}{|l|l|}
\hline \multicolumn{2}{|l|}{ Table 2: World PrimaryCommodity Prices, 2002-2006 (Percentage Change) } \\
\hline Commodity group & $2002-2006$ \\
\hline Food and Tropical Beverages & 48.4 \\
\hline Agricultural raw materials & 62.3 \\
\hline Minerals,ores and metals & 219.9 \\
\hline Crude petroleum & 157.6 \\
\hline
\end{tabular}


Source: UNCTAD Secretariat calculations, based on UNCTAD Commodity Price Bulletin, various issues, and UNSD, Monthly Bulletin of Statistics, various issues. Adapted from UNCTAD (2007A).

The increased value of SSA exports as a result of the commodity price rise helped to relax the balance of payments constraint which in turn led to faster growth. Assuming continued favourable terms of trade, the central issue is whether or not the African countries can translate this recent improved performance into sustained, fast and long term economic growth. Here, though, the economic history of these countries in the last half century does not provide much ground for optimism. The good record of African economic growth between 1950 and 1973 when these economies expanded at a rate of nearly 5 percent per annum could not subsequently be sustained. Similarly, during the 1990s a number of countries were successively selected as the 'African success stories' by the Bretton Woods institutions, none of which could actually maintain fast growth for more than 2-3 years (Mkwaindaire, 2005). Such economic history invites scepticism about the ability of African countries to convert their recent favourable changes in the terms of trade into lasting progress. The case of the sceptics is straightforward. Apart from all the other handicaps, the African countries have been further debilitated by two decades of stagnation or worse; and therefore seem unlikely to achieve fast long term growth.

There are however important counter arguments which are equally an essential part of the story. The African countries are today much better equipped for initiating and sustaining fast growth, with a far greater endowment of human and material resources than they were 25 years ago.

- The educational level of Africa's citizens is much higher today than it was in the early 1970 s. This is particularly notable at the tertiary level. There were for example only 7 university graduates in Tanzania in 1964 at the time of the country's independence from British colonial rule. Today, after independence there are literally thousands, as a result of the establishment of the University of Dar-e-Salam, a splendid institution of higher education. 
- There is a network of science and research institutions, engineering colleges, throughout the continent. A number of business schools have also been established and there is now close collaboration between the African and the best business schools in the US and the UK (Pfeffermann, 2008).

- There are signs of an emerging middle class in African countries. There is evidence also of the evolution of entrepreneurship in these countries (ibid.).

- Moreover, as The Economist (2008) notes, "an unexpected and overlooked continent may benefit from its very isolation" (p.33). It suggests by way of illustration that African banks are normally regarded as being very conservative and excessively regulated. 'Now, however' observes The Economist (2008), "this very de-linkage from the Western financial system has turned out to Africa's advantage. Its banks have almost no exposure to the sub-prime market causing such havoc elsewhere."

With the above background, this paper considers the question of industrial policy for African countries and what lessons they can draw from the experience of other countries. As latecomers to industrialization, the African countries are well placed to carry out such an exercise. Economic history of the last half century indicates that whereas industrial policy has been highly successful in some countries, it has been equally unsuccessful in others. The African countries would wish to draw appropriate lessons from both sets of countries. There is, however, a prior question which they obviously need to consider. Should they have an industrial policy at all? Here the experience of the East and South Asian countries does indicate that industrial policy has played a key role in the extraordinary success of these economies in recent decades. ${ }^{3}$ In addition to this there is another related and powerful reason for African countries to examine

\footnotetext{
${ }^{3}$ Amsden(1989) and Wade (1990) are two well known representative studies from the huge literature on this subject.
} 
closely the experience of Asian countries. Many countries in the two regions at the time of independence from colonial rule had broadly similar economic structures and income. To illustrate, in the 1950s around the time of the country's independence, Malaysia's economy was much like that of Ghana, based on exports of primary agricultural commodities, rubber in case of Malaysia and cocoa in relation to Ghana. Both countries shared the common legacy of British colonial rule. However, today, the Malaysian per capita income is nearly 5000 USD at current exchange rates and 10,000 USD at PPP rates, while the Ghanian per capita income has risen very little over the same period. It is legitimate to ask how can one account for such difference in the evolution of the two economies? Was it, for example, simply due to the fact that the Ghanian economy was subject to greater economic shocks than Malaysia's? There is little empirical support for this hypothesis. Moreover, a large number of other East and South Asian countries also did very well using industrial policy and outperformed most African countries. For these reasons comparisons of African countries with East and South Asian countries are commonly made and and are useful. However in this paper we consider only briefly the experience of East Asian countries with industrial policy, but give detailed attention to Ireland as a comparator, and present the reasons for doing so.

The next section briefly explains why Ireland is an interesting comparison for African countries and why lessons from the Irish experience will be useful. Section 3 to 8 then discuss in greater detail the role of industrial policy in a broad sense as well as other important factors in the development of the Irish economy, together with the lessons for African countries. Section 9 re-examines the case of East Asian countries as role models for economic development for African countries. Section 10 concludes. Close attention to the Irish case does not of course imply that other countries' experiences are less important or less relevant, but we believe that Ireland's experience with industrial policy does have useful and significant implications for Africa. Nevertheless, for African countries, at a practical policy level, we would like to endorse the caution from Professor Karl 
Aiginger, one of the leading industrial policy economists in Europe. Aiginger (2007) notes that 'industrial policy is one of the most controversial policy fields... Its scope, instruments and rationale vary across countries, changing over time; intentions and outcomes often differ' (p. 143).

\section{Why is Ireland an Interesting Comparison for Africa?}

When Ireland joined the 'Common Market' in 1973, the economy was in many senses a small, poor, peripheral and agriculturally dominated economy with an overdependence on links to its former colonial master, the UK. Trade was limited given ongoing protectionism (it is worth noting that the European Union (EU) in particular had yet to fully open up). Within three decades, however, the Irish economy has transformed itself from being one of the four cohesion countries of the EU to being considered an advanced high-tech enclave of the EU.

There are also other reasons for using the Irish example:

- Ireland, like most African countries is a small economy. It has the geographical size of Sierra Leone as well as a similar population. Given its small size, membership of the EU has played a major role in the evolution of the Irish success story. As well as providing a far larger market for Irish products so as to be able to reap the economies of scale, the EU has also provided Ireland with very large direct assistance for the development of its infrastructure. What could take the place of EU even in a limited sense in the present context of small African countries? This issue will be taken up below.

- Although Ireland is far from being a laissez-faire economy it is by no means as 'dirigiste' as the East and the South Asian countries. In particular, it has been more corporatist than the East Asian countries. The unions have played a major role in the determination of wages and prices. Compared with the East Asian model it is therefore more likely to be directly relevant to the African countries. The East and South Asian pattern of development is heavily dependant on the outstanding 
qualities of the civil service. These are not simply inherited or endowed but rather are developed alongside the expansion of the economy (see Chang, 2006). Nevertheless, the corporatist model makes comparatively less demands on administrative capacity.

- It is arguable that the African countries would have more to learn from the experience of the operation of industrial policies in Ireland than in the East and South Asian countries. The Irish industrial policy did not involve measures of coercion in the allocation of resources in the way it did in the case of East Asian countries during the height of their industrial policy, for example, Japan between 1950 to 1973, and Korea between 1970 to $1990^{4}$. It is worth recalling that during this period the Japanese government used the allocation of foreign exchange in coercive ways as a key weapon to meet government's targets for specific firms and industries (Brown, 1980). Similarly during Korea's main industrial policy period, there is evidence of coercion in the expansion and upgrading of country's exports by the Chaebol, the large conglomerates which the government itself had created (see Amsden (1989,1994), Amsden and Singh (1994), Singh (1995,1998), Chang (2006)).

- It should not be forgotten that during the operation of industrial policy in a number of East Asian countries, industrial 'peace' was ensured (or enforced) through the suppression of trade union rights. Some would argue that this alone makes the Irish example more suitable as a role model for African countries.

The following sections examine in more detail the operation of industrial and developmental policies in Ireland and their relevance for African countries, before returning to some more positive 'lessons' from East Asia.

\footnotetext{
${ }^{4}$ These were the high growth periods for the two countries. In 1973 Japan was still more like a developing country than it has been since. See further Singh (1995).
} 


\section{SMEs in Ireland and in African Countries}

The similarities in economic experiences between the Irish case in the (not too distant) past and that of many small African states today warrants research to provide insights as to whether Ireland can regarded as a useful case study, especially around the development of small and medium sized enterprises (SMEs), especially given their importance in both Ireland and small African states. Of relevance here, some characteristics of Irish SMEs can be noted:

(1) Irish SMEs were focussed primarily upon the home market. Indeed, export oriented SMEs were an uncommon occurrence in the Ireland of the 1970s.

(2) Ireland's small manufacturing firms in the past were mostly found in 'traditional' industries (such as food, beverages and tobacco, textiles and wood products). These industries were characterised by low productivity, skills and research and development (R\&D).

(3) Small firms in Ireland were then faced with similar barriers as small firms in Africa today (albeit on a different scale), namely: financial barriers (particularly at the start-up stage); and poor macroeconomic conditions, as well as a poor business environment. ${ }^{5}$

Until recently, there has also been no well-defined, structured or focussed policy for support of SMEs in Ireland. As we shall see below, industrial policy in Ireland has mostly been geared towards FDI and it could reasonably be argued that this has been at the expense of indigenous companies. This has some similarities to Africa, where an adverse business environment (with little support from government agencies, the regulatory offices and the managers of state enterprises) is an additional impediment for small firms.

\footnotetext{
${ }^{5}$ On the latter point, numerous studies on the barriers encountered by small firms in Ireland have pointed to access to finance as being the single most critical issue (Forfás 1994; Goodbody Economic Consultants 2002; Global Entrepreneurship Monitor 2001). Very recent work on the Irish case shows that small businesses continue to experience difficulties in obtaining appropriate levels of finance for start-up and growth (Small Business Forum, 2006). This finding has been reiterated in recent work with regard to small firms in Africa.
} 
Despite these apparent similarities, one key aspect missing in the African case is the benefit of European integration in the form of the single market. When Ireland joined the then 'Common Market', there was a lack of developed common policies outside of the already well-developed the Common Agricultural Policy (which at the time absorbed three quarters of the EC budget). Over time, though, there have been two ways in which EU economic integration has brought substantial opportunities for small firms: (i) through reciprocal recognition of standards in the Single Market through the Acquis Communautaire and (ii) through the benefits emanating from structural funding, particularly in the sphere of infrastructural development. The latter has brought significant benefits to Ireland. Beyond the costs associated with the Acquis, it can generate many advantages to small firms in the medium to long run, as they will be able to benefit from the Single Market. This, combined with deregulation in the EU also assists cross border trade by small firms engaging in flexible specialisation. Finally, the Single Market is also helpful in attracting market-seeking FDI, an element which is very much missing from the African case.

From its post World War II beginnings in the European coal and steel community, the EU has evolved into an integrated single market in the region of 450 million people. At the time of writing, fifteen member states have also adopted a common currency and a common monetary policy together with many other measures of deep political integration. Such far reaching integration is well beyond the capacities of SSA countries. However, there are substantial benefits, economic as well as political, even from the limited regional integration which some countries have attempted. There are also a few reasonably well functioning examples of integration in African countries, notably in Southern Africa. The emphasis in the more successful of these late integration projects has been less on trade integration but more on integration of transport as well as in other spheres of infrastructure. Over time these countries could potentially cooperate on monetary matters as well as on trade and investment. The possibilities of 
African economies to be able to benefit from the kind of assistance which Ireland received from the EU may not appear to be a practical proposition for African countries, however. Yet it may not be entirely fanciful, either. Who is to say that to acknowledge the contribution of Afro-Americans to building up modern United States, let alone to right the historic wrongs, a possible President Obama may not launch the equivalent of a Marshall Plan for African countries? Such a plan should encourage regional integration on the E.U. pattern, leading ultimately to deep integration. Even if such a grand vision does not materialise, the essential point is that ODA to African countries should be used to encourage regional integration to create a larger market for firms in participating countries as well as to provide funding for the development of regional infrastructure.

\section{Viewing Development in the Round: The need for a Holistic Approach to Policy}

Commonly adopted definitions of industrial policy are too narrow where the key focus, particularly in the past, has been on grant-aiding firms and intervention with respect to particular sectors, even with a more recent focus on policies focused directly at the promotion of R\&D and innovation and/or FDI and SMEs. In general terms throughout Europe there has been a swing from 'capacity' building, with a focus on subsidies for capital and employment towards 'capability' building, with a focus on R\&D and training interventions by policymakers. We argue that good practice industrial policy is in fact much more 'holistic' than the above and focuses simultaneously on both demand and supply side factors of industrial development; on micro economics, meso economics and macro economics. ${ }^{6}$ Such an approach is broadly in line with that suggested by

\footnotetext{
${ }^{6}$ Singh (1995) comments on the inter-relationship between industrial policy and macro economic stability with particular reference to the experience of East Asian countries. To the extent that industrial policy was effective in Japan or the Republic of Korea in relieving the balance-ofpayments constraint, it will also have aided macroeconomic stability. A current account balance at the desired growth rate can help to avoid the stop-go cycles which many economies experience. This, in turn, will lower the cost of capital since for a given savings rate in the economy, other things being equal, the more variable and unstable the economic performance, the higher the interest rate. Similarly, faster economic growth also leads to faster growth of real wages, and hence enhances social stability and the political legitimacy of the socio-economic
} 
the 'Culliton Report' (1992) in the context of Irish industrial policy. Culliton (1992) emphasised provision of infrastructural needs; reform of the tax system; a refocusing of the education and training system; increased funding for science and technology (coupled with greater involvement by industry in steering the use of these funds); and a greater emphasis on technology acquisition. In so doing, the report stressed keeping the role of the industrial promotion agencies under review, as well as the desirability of fostering clusters of related industries building on 'leverage points' of national advantage was also highlighted.

As for indigenous industry, Culliton saw the widespread existence of grants as being often counterproductive (the argument being that it encourages a hand-out mentality). In this vein, more emphasis should be placed on: the increased use of equity finance as opposed to non-repayable cash grants; an emphasis on the need for the expansion of the indigenous sector; a reorganisation of grant awarding agencies into two main agencies, one of which would address the needs of foreign-owned industries, the other the needs of indigenous ones. Culliton was also at pains to stress that the Irish Department of Industry and Commerce was overly focused on operational matters and needed to place industrial policy formulation and evaluation at the centre of its activities. We argue that a 'good practice' definition of industrial policy includes all of these but also needs to emphasise other factors such as well functioning labour and credit markets, an appropriate macro-environment, and attempts to build consensus over appropriate policy direction.

We broadly agree with Hitchens and Birnie (1992) in their commentary on evaluating the Culliton report that the real challenge is to try to weigh the importance of the above factors with regard to the overall 'competitiveness problem' (we would however be more inclined to see this as the industrial or economic development challenge). With reference to improving competitiveness (or in our case industrial or economic development) the authors correctly point

order. Thus, macroeconomic stabilization and industrial policy interact with each other in a virtuous circle of cumulative causation. 
out that there is little point calling for the need to improve competitiveness "... without any satisfactory definition that can be operationalised" (p. 29). They proceed to argue that "this lack of identification of its causes and hence effective solutions is an impediment to a satisfactory industrial development policy" (ibid). Therein of course lays the challenge for policymakers regardless of country.

Thinking back to Ireland's less favourable times, the preface to the Culliton report (1992) opens its narrative with the following comment: "over the past six months we have considered industrial policy bearing in mind the 260,000 people who are unemployed. We have concluded that there are no short term solutions, no quick fixes and no soft options left" (p. 7). In addition, it notes; "Ireland's economic problems are deep-rooted and persistent. Their resolution will require patience, determination and a fundamental re-appraisal of our strengths and weaknesses" (p. 7).

A more 'holistic' view of industrial policy also recognizes that organizations operate within a system whereby many factors and policies from a plethora of other areas impact on the success or otherwise of these organizations. An example of the latter can be seen when we look at the case of innovation policy. Any analysis by policymakers or researchers needs to take account that organizations are not innovating in isolation but in the context of a system ${ }^{7}$. We would argue that Aiginger (2007) in his special issue on the future of industrial policy follows a similar line to the 'holistic' definition of industrial policy put forward in the current paper when he outlines that "The upcoming new approach to industrial policy all hints at a more systemic industrial policy, forward looking and emphasizing the synergies with other policy areas, but also fine-tuning to specific needs, comparative advantages and future technologies" (p. 143).

\footnotetext{
${ }^{7}$ For further discussion on the systems perspective of innovation, the interested reader should refer to Matcalfe (1994).
} 
In line with this broad and holistic view of what industrial policy should encompass, in the Irish case we can identify a range of factors which played a significant part in Ireland's recent 'catch up'. These comprise:

(1) Currency devaluations in both 1986 and 1993. These were locked into the single currency, with the Euro's post-2000 depreciation in turn benefiting outward orientated states such as Ireland (of course, this has more recently been reversed);

(2) A series of corporatist social pacts from 1987 where trade unions limited wage increases in return for income tax cuts. These have allowed rapid growth without inflation rising excessively and have also enabled rapid employment growth;

(3) A rapid expansion in labour supply, in part through net in-migration. ${ }^{8}$ More widely, the demographic shifts Ireland has experienced are unique within the EU, with an even balance between natural growth and migration (Salt 2005: 49) ${ }^{9}$;

(4) An interventionist industrial policy targeted certain sectors for FDI (industrialization by invitation) yet also recognised the limitations of FDIbased growth and somewhat belatedly sought to better link foreign plants with domestic firms and tried to develop indigenous capabilities and improvements in entrepreneurship, labour skills and research and development.

This analysis has implications for the design of industrial and other policies in other small, open and peripheral economies. We suggest that whilst important lessons may be learned, they may not be those picked up by mainstream commentators such as Sapir et al (2003). Furthermore, it should be noted that a range of factors came together: some more by luck than by judgement, and that

8 Ireland has the highest fertility rate in the EU, and between 1981 and 2001 experienced a population increase of 15 per cent, from 3.5 million to just over 4 million in 2004 (NESC 2005: 1).

${ }^{9}$ UNCTAD $(2007 ; 25)$ notes that monetary or non-monetary resource transfers by migrants to their home countries are increasingly recognized as an important source of financing for development in Africa, being the second largest source of development capital flows to developing countries. 
the Irish catch-up should have happened much earlier had it not been for previous policy mistakes, particularly at the macro-level (Bailey et al, 2007).

Indeed, on the macroeconomic-side, stabilisation was an important part of finally 'getting things right' in Ireland. By the mid-1980s, the fiscal deficit in Ireland had grown to over $12 \%$ of GDP and the public debt ratio was approaching $120 \%$. The recognition of the need to address these imbalances led to both the social pacts after 1986 and a process of fiscal consolidation achieved by the government reducing expenditure; over the two year period 1988-1989, the ratio of expenditure to GDP was reduced by $9 \%$ (see Bailey et al, 2007). The pain of this adjustment was eased both by EU funding and an improved external environment with reduced interest rates and improving demand (Lynch, 2005). ${ }^{10}$ Of key relevance, the impact of EU structural funding assistance starting in 1988 should not be underestimated: one study suggests that the cumulative effects of funding may have been to raise the level of GDP by over 4 per cent (Schweiger and Wickham, 2005: 50). Another suggests at least approximately 0.5 of a percentage point to GNP growth during the 1990s (Barry et al, 2001: 549). In other words, external funding gave Ireland enough space to stabilise its macro economy and to undertake investment (especially in infrastructure) designed to enhance competitiveness; this may be relevant for African economies in the context of overseas development assistance. Similarly, in the Africa case, UNCTAD (2005; 34) notes that overseas development assistance (ODA) could trigger such a "growth process if it is focused on financing pro-growth public investment such as economic infrastructure".

\footnotetext{
${ }^{10}$ Quite why the Irish economy prospered at this time when the state pursued a very restrictive fiscal policy has been the subject of much debate. The European Commission saw it as an "expansionary fiscal contraction" which led to improved confidence and greater consumption and investments (EC Commission 1991; McAleese 1990). Others have stressed the Lawson boom in Britain which raised demand for Irish products and fall of the oil-prices; "Irish policy makers were just lucky that their adjustment was carried out at a time when world growth became buoyant and world interest rates were falling" (Bradley et al. 1993). Kennedy (2001: 131-2) also suggests that growth in the US economy and the advent of the Single Market after 1993 were important factors.
} 
In addition, in the Irish case, currency depreciations which took place in 1986 and 1993 assisted Irish competitiveness; the latter in particular was a 10\% depreciation which was then locked into Euro entry. Whilst there was a revaluation of the Punt before Euro entry in 1998, the depreciation of the Euro after its launch delivered a further $20 \%$ boost to Irish competitiveness given its external-orientation in trade towards non-Euro zone economies. That this did not feed through into higher inflation is in part due to a number of corporatist social pacts which built consensus.

Such corporatism has been a long-standing central feature of Irish economic policy, with the establishment of the National Economic and Social Council (NESC) in 1973. As noted, by the early 1980s, Ireland faced a 'crisis' as the government had embarked on deficit-financed expenditure programmes after the oil price rise of the early 1980s (and indeed the early 1970s). The existing development strategy based on attracting FDI was also criticised for its failure to support domestic industry (Telesis, 1982; Culliton, 1992). Trans-nationals responded to the crisis by cutting investment and repatriating profits, contributing to a deficit on the balance of payments amounting to around 10\% of GNP. Meanwhile, unemployment rose to around $20 \%$ of the labour force.

At this crisis point, the major political parties recognised that an expansionary fiscal policy was no longer an option for Ireland as a small open economy. A social consensus for change emerged. Key to this was the proposal by the trade unions in 1984 for a coordinated approach involving income policies, or 'partnership agreements'. Indeed, Kennedy (2001: 135) argued that without partnership agreements, it is unlikely that unions would have tolerated a rise in the profit share of national income (see below). Developing a shared view of 
what needs to be done certainly seems to have been a key element in enabling the Irish catch-up. ${ }^{11}$

Between 1988 and 2005 there were six social partnership agreements between government, unions and employers. The original programme was the Programme for National Recovery (PNR) which ran from 1987 to 1990. The PNR set out a strategy to raise competitiveness with four main components, which were developed over time in subsequent partnership agreements, with later agreements having broader coverage (including chapters on greater social inclusion, equality, enterprise culture, small business, agriculture, public service modernisation and a commitment to support partnership at the enterprise level):

- Reducing the level of public debt and maintaining the internal and external stability of the Irish currency. This has focused on creating low inflation and interest rates and a positive climate for investors. From the mid 1990s onwards this has tied into the EU's Maastricht Criteria and Stability and Growth Pact (SGP).

- Restraining wage rises in order to improve cost competitiveness. An incomes policy became an essential part of the 'new development strategy'. In return, the government compensated for wage restraint by lowering income taxes, although recently this has perhaps reached the limits of what is achievable.

- To enhance competitiveness, pacts have included structural reforms in several areas such as industrial policy and taxation. The latter was seen as needing reform to encourage employment creation, being seen as biased towards capital and property.

- Social justice has been seen as important and there have been improvements in welfare payments for the least well-off.

The Irish experience, then, suggests the importance of strong institutional

\footnotetext{
${ }^{11} \mathrm{MITI}$ (the Ministry of International Trade and Industry) in Japan may have played a similar consensus-building role after the Second World War through to the 1980s (see Bailey and Sugden, 2007).
} 
arrangements in fostering social cohesion around development objectives. In addition to this, as Andreosso-O'Callaghan and Lenihan (2006) detail, a range of other factors came together to enable Ireland to catch up with other European economies, including:

- Progression towards a modern telecommunications network; this was significantly helped by the decrease in telecommunications costs which subsequently reduced the real costs associated with firm location in a peripheral economy such as Ireland.

- Human capital accumulation: In contrast to other peripheral host countries for foreign investment, Ireland had a relatively skilled (and English speaking) labour force. Yet it is worth noting that rapid economic growth in Ireland has taken place without much investment in innovation. By EU and international standards, and in spite of its relative current wealth, Ireland still suffers from a low $R \& D$ to GDP ratio (and/or $R \& D / G N P$ ratio). In contrast with one of the key lessons advocated by mainstream commentators, modern economic growth in Ireland does not owe much to innovation.

- Competition policy and deregulation: The introduction of competition policy and deregulation in the early 1990s was important in terms of delivering on cost competitiveness for firms using Ireland as an export platform (see Braunerhjelm et al., 2000).

- A shift in the type of products being traded internationally: Geographical disadvantage may not count as heavily anymore. As Krugman outlined: "...changes in both the nature of what nations trade and in how they carry out that trade has shifted the balance of geographical advantage in a way that is favourable to Ireland" (Krugman 1997; 44).

In referring to this well-rehearsed debate regarding Irish growth, we simply wish to stress that there were many factors which contributed to the success of the Irish economy particularly from the mid 1990s onwards, and the industrial policy approach adopted by the Irish government was only one feature in the myriad of 
factors which contributed to the Irish success story. Yet we would still suggest (see below) that there may be potential for government intervention in the SME sector in small economies such as those in sub-Saharan Africa to lead to significant improvements in the key growth indicators of these countries.

\section{Using Foreign Direct Investment Intelligently}

It is widely recognised that foreign direct investment (FDI) flows to Africa, although increasing, are "still too limited in geographical coverage and focused on extractive industries to have a significant effect on employment creation and poverty alleviation" (UNCTAD, 2007; 1). A key cause of this is the high degree of risk and poor business environment, which deters FDI. According to UNCTAD $(2007 ; 46)$, these impediments include “(a) poor infrastructure, (b) high entry costs, (c) labour market constraints, (d) low investor protection, and (e) high taxes and a cumbersome tax system". On the tax front, UNCTAD (ibid) notes that a typical firm in sub-Saharan Africa pays the equivalent of $71 \%$ of its profits in taxes, some $15 \%$ percent higher than the second-highest rate, paid in Europe and Central Asia.

In sharp contrast, FDI, notably from the United States, has been a major trigger for economic growth in Ireland. Indeed, relative to the size of the economy, Ireland has one of the highest levels of FDI inflows in the world. Whilst successive Irish governments have welcomed FDI since the 1950s, from the early 1970s onwards the government approach shifted towards a greater emphasis on selectivity and careful targeting, with pharmaceutical and electronics especially targeted. These industries were ideal for peripheral locations in that they were characterised by relatively low transportation costs and high growth rates (Braunerhjelm et al, 2000). Furthermore, the US was targeted as the most probable market for such projects given the likely benefits that would accrue to US firms using Ireland as an export base within the EU. The promotion and assistance of particular sectors was well timed. For example, the extension by the Irish government of financial incentives to internationally 
traded services just as they were about to grow in importance was a particularly timely intervention. Later, during the 1990s, industrial clusters in such sectors began to develop which involved linkages, spillovers and sub-supply relationships with SMEs (see below). There was also a demonstration effect in operation, whereby the positive experiences of foreign investors in Ireland stimulated further FDI. If such strategic targeting and a more focused approach to FDI was a key part of the contribution of FDI to Irish development, this raises the question as to what sectors should small African countries now be targeting?

Whilst the high levels of FDI were largely brought about by a corporate-friendly environment offering the lowest corporate tax rate in the EU, it should be noted that these tax breaks had existed for decades with limited impact on economic success. Moreover, other European economies have had such rates without attracting such levels of US FDI - in part this may be because of the cultural links between Ireland and the US where many US citizens can trace their ancestry back to Ireland, a factor which cannot be replicated or seen as a 'lesson' for others. Similarly, House and McGrath (2004) note that the emphasis on education and training and a favourable corporate tax environment were both already in place before the mid-1980s when the economy was still stagnating (ibid.). Of particular note was the recognition by the Irish government in the late 1970s and early 1980s that foreign transnationals were in effect branch plant operations and that the policy of heavily subsidising FDI was producing little in the way of wider spillovers for the economy. Because of this, policy began to adopt a more selective approach to FDI, focusing more on high-tech and higher value added firms. Transnational firms' motivations for FDI in Ireland also shifted at this time, towards accessing the single market and access to skilled labour.

It should be noted that problems and challenges remain and that the picture of FDI-induced 'transformation' is challenged by some. A key 'lesson', as we shall see below in more detail, would actually be that spillovers from FDI are not generated automatically and that an industrial policy that targets and positions FDI is vital to ensure wider spillovers and to benefit the domestic sector. The 
case is not anti-FDI per se; rather, we recognise the value of high-quality FDI in assisting economic development. Rather, it needs to be stressed that this should not come at the expense of ignoring domestic firms. In a related vein, Buckley et al (2006) argue that the contribution of transnationals to the Irish economy can also be overestimated by failing to take account of the following: the high level of imports (including payments for patents, royalties and other tangible inputs) and repatriated profits. Citing the work of Keating (2000), the authors show that "...sales amounted to $€ 72$ billion in 2004 . However, when imports of $€ 43$ billion and profit repatriation of $€ 19$ billion are deducted the direct contribution to GNP is only 10 billion" (Buckley et al 2006: 2).

Attracting high-quality FDI and positioning it seems crucial. Here, lessons with FDI experiences in peripheral regions of the EU seems highly relevant in taking on board elements of 'good practice'. This includes targeting strategic sectors and linking FDI to cluster development, building trust with local managers in order to try to upgrade local plants, undertaking sector specific research on the strengths and weaknesses of local industry, providing aftercare support, targeting financial assistance at specific upgrading needs (e.g. investment in R\&D rather than general support), and the monitoring of performance (see Amin and Tomaney, 1995; Bailey et al 1999). The Irish experience of selectively targeting FDI seems very relevant here and raises the issue more generally of using selective as well as horizontal industrial policy. ${ }^{12}$

The discussion of this section will be seriously incomplete without reference to the fact that in the practice of industrial policy in East Asia, both Japan and South Korea discouraged FDI rather than to seek it. Singh (1995) noted that among developing countries, the Republic of Korea was second only to India in its low reliance on FDI inflows. Foreign capital stocks totaled just 2.3 per cent of GNP in

\footnotetext{
${ }^{12}$ See Bailey and Cowling (2007) who note that industrial policy in the US and Japan has involved both vertical measures in targeting new technologies and emerging industries, and horizontal measures to support all industries, suggesting that the current focus in Britain and the EU with the horizontal aspects of industrial policy has been largely misplaced.
} 
1987 for the Republic of Korea, above the 0.5 per cent estimate for India, but far below the levels of 5.3 per cent for Taiwan Province of China, 17 per cent for Hong Kong, a massive 87 per cent for Singapore, 10 per cent for Brazil and 14 per cent for Mexico (UN, 1993). In the view of the World Bank economists, this discouragement was a self-imposed handicap, which was compensated for by the fact that both countries remained open to foreign technology through licensing and other means (East Asian Miracle, p.21). Singh noted that World Bank economists did not ask the question: if the governments of Japan and the Republic of Korea were as efficient and flexible in their economic policy as they themselves suggested (to account for their long-term, overall economic success), why did they persist with this apparently wrong-headed approach for so long? Indeed it was not until the 1990s that Japan really finally opened up for inward FDI (Bailey, 2003).

Perhaps the approach was not so wrong-headed after all? It was "functional" within the context of the overall industrial policies which the two countries were pursuing. First, it would have been difficult for MITI or the authorities of the Republic of Korea to use "administrative guidance" to the same degree with foreign firms as they were able to do with domestic ones. Secondly, as UN (1993) rightly emphasized, there was a link between the national ownership of large firms and their levels of investment in research and development. The Republic of Korea had, in relative terms, by far the largest expenditure on R\&D among developing countries: 1.9 per cent of GNP in 1988, compared with 1.2 per cent for Taiwan Province of China (1988), 0.9 per cent for India (1986) and Singapore (1987), 0.5 per cent for Argentine (1988), 0.6 per cent for Mexico (1984) and 0.4 per cent for Brazil (1985). Korea's performance in this area outstripped that of many developed countries- for example Belgium (1.7 per cent in 1987), Denmark (1.5 per cent in 1987) and Italy (1.2 per cent in 1987). It was, of course, still below that of industrial super-powers, Japan (2.8 per cent in 1987) and Germany (also 2.8 per cent in 1987). Thirdly, Freeman (1989) stressed another important advantage of the policy of mainly rejecting foreign investment 
as a means of technology transfer. This, he argued, automatically placed on the enterprise the full responsibility for assimilating imported technology. This was far more likely to lead to total system improvements and broader spill-overs than the "turn-key plant" mode of import or the foreign subsidiary mode.

It is important to emphasize that Japan and South Korea's rejection of FDI did not mean that these countries are not interested in importing foreign technology. Quite the contrary. Japan after all has been attempting to obtain technology from abroad for a hundred years, with an emphasis on licensing, joint ventures and foreign involvement rather than FDI. The reason why it did not favour FDI as a source of technology was that it was inter alia comparatively much more expensive than licensing. The latter was a policy pursued by Japan up to the 1980s, when under pressure from the US it began finally to dismantle such barriers and started to allow in FDI without requiring a Japanese joint venture partner (Bailey and Sugden, 2007). Such considerations may also be valid for at least some SSA countries who may also prefer to import technology through licensing rather than through the medium of FDI.

\section{Fostering Domestic Enterprise}

Authors such as Bailey et al (2007), have argued that the Irish government, on recognising the limitations of solely focusing on FDI as an engine of growth, also sought to develop indigenous small and medium sized enterprises (SMEs) and entrepreneurship more generally. Whilst recognizing this argument, we stress that this focus on indigenous SMEs and entrepreneurship by Irish policymakers should have come much earlier. Despite the fact, as outlined by AndreossoO'Callaghan and Lenihan (2006: 282), that "...even as far back as 1979, some 95 per cent of all manufacturing units could be classified as SMEs", it is nevertheless remarkable that there was no formal focus by the Irish government on the small firms sector per se until 1994 with the publication of 'The Task Force on Small Business Report' (1994). 
One can convincingly argue that the Irish government to a large degree overlooked the indigenous (largely SME sector) until the mid 1990s. As such, this represents a key policy 'failure' and should be avoided by small African states. Admittedly, in the Irish case there were grants available to indigenous firms to start-up and expand - but the focus on indigenous and SME firms was overshadowed by the prime focus by the Irish government on FDI. This is evident in comments from various reviews of industrial policy over the decades; most notably the 'Telesis Group' (1980), which highlighted an over-emphasis on foreign industry. The Culliton report also emphasised the need to expand the indigenous sector. However, it was not until the 'Task Force on Small Business Report' published in 1994 that the focus on the SME sector by Irish policy makers truly began in earnest.

Some of the challenges facing small firms in Ireland are similar, albeit in a much more intense form, in Africa, most notably the issue of access to finance. As UNCTAD (2007) notes, this is especially the case for the small domestic enterprises in the informal sector that represent the vast majority of firms. Indeed, it is thought that firms in sub-Saharan Africa fund between one half and three quarters of their new investments from their own informal savings. In order to address this, microfinance systems have emerged in recent years in order to address some of the shortcomings of the financial system in Africa.

More generally, Acs et al (2007) suggest that entrepreneurs in Ireland are held in high esteem, and that this has been beneficial for the economy. This is questionable, however, and Culliton (1992) highlighted "...the negative attitude towards enterprise that is prevalent in this country" (p. 22), with a "...a deeprooted prejudice against failure in business. The stigma that attached to a failed enterprise very often inhibits the individual from ever trying again" (p. 22). Perhaps it could be argued that such a negative attitude no longer exists. However, ten years later from Culliton, Goodbody Economic Consultants (2002), although acknowledging an improvement, still noted that the "non-acceptance of 'failure', both on the part of financial institutions and the general public is still 
perceived to be an issue by Irish entrepreneurs" ( $p$. iv). They do however, admit that "these attitudes are somewhat at variance with recent international studies which indicate that the general public's attitude towards entrepreneurship in Ireland is now highly favourable" (p. iv).

\section{Embedding Growth through Spillovers, Linkages and Clusters}

There was an expectation and hope in Irish industrial policy circles that indigenous SMEs would '... grow from foreign firms through linkages and spillovers' (Andreosso-O'Callaghan and Lenihan, 2006: 280). This spillover argument is often used by governments to justify subsidies for FDI, but it is well known that such spillovers are not guaranteed. It is to this issue that we now turn, asking how successful (where they existed) were Irish Government policy interventions in achieving successful linkages and spillovers between incoming transnationals and indigenous (largely SME) firms? This is significant as some authors see this link as a key element of the Irish 'success story'. For example, Pike et al (2006; 233) suggest that:

'the role of industrial policy... seems important, with the Irish state and its governance institutions proving adept at providing the kinds of territorial assets that attract the sorts of TNCs that will contribute to development. Ireland may provide an example of a somewhat 'strategic coupling' between domestic and foreign owned firms....

The FDI literature tells us that, if present, positive spillovers from transnationals can lead to increases in the productivity of domestic firms. This can happen via three main routes: (1) demonstration effects; (2) competition effects, and; (3) labour market effects. As noted, spillovers are not generated automatically but are in essence driven by the characteristics of the host economy, such as its degree of economic development, its ability to assimilate imported technology and more generally its absorptive capacity (see Blomström and Kokko, 1996 and Blomström et al. 2000). In this section we briefly highlight the key evidence regarding the prevalence of such linkages and spillovers in Ireland. Most 
notably, despite the rhetoric of 'FDI-led adjustment', there is significant evidence to suggest that the Irish economy operates according to a Lewis-type dualism "...with little relationship / interdependence between MNEs and (local enterprises) and each developing according to its own pattern" (Ugur and Ruane, 2004: 3). As such, each sector appears to have developed according to its own pattern. Such problems of 'dualism' remain a major problem in many developing economies; for example UNCTAD $(2007 ; 6)$ notes that in Africa, FDI is "... relatively volatile and tends to focus on extractive industries with very few linkages to the domestic economy".

In the Irish case, there is evidence from some sectors at least of improved linkages over time, such as in electronics (see Görg and Ruane, 2000; 2001), even if foreign (particularly large) firms have lower linkages - perhaps due to the necessary scale needed to supply such firms (ibid.). Other authors (e.g., Kearns and Ruane, 2001) suggest that the level of $R \& D$ activity in a plant is a key determinant with regards to lengthening the duration over which that plant will stay in Ireland, and also with respect to improving the quality of the employment generated in the plant. For high-technology sectors, the evidence of spillover effects is even more evident (Görg and Strobl, 2002; 2003; Barry and Van Egeraat, 2008). Here, there is evidence to suggest that the presence of transnationals in high-technology sectors has had a "life-enhancing" effect on indigenous plants in Ireland, improved indigenous entry rates, and has improved links between manufacturers and components suppliers in sectors such as IT.

Other contributions (by Heanue and Jacobson, 2003; Forfás 2004; Lenihan and Sugden, 2008) have explored the issue of linkages in Ireland. Lenihan and Sugden (2008) argue that the National Linkages Programme introduced in 1985 was partly in response to criticism of an industrial policy approach by Irish government that relied on transnationals and was subsequently restructured by Enterprise Ireland with a focus surrounding the issue of the globalization of local 
supply industry. This approach resulted in a move towards the building of supply networks and chains as opposed to actual direct local company linkages. Forfás (2004) in analyzing the impact of the National Linkages Programme argued that it stopped short of reaching its potential, while Heanue and Jacobson (2003) argued that there was some success up to the 1990s but thereafter the impact was insignificant. In terms of more traditional sectors, Culliton (1992: 31) argued that only a small proportion of potential linkages between foreign and traditional firms were being realized; and that "[i]n general,.... policy to promote industrial linkages has not lived up to its expectations. It is only a mild exaggeration to say that most of the newer foreign firms operate here as essentially an industrial enclave" (ibid.). The overall conclusion on the success or otherwise of linkages in Ireland is succinctly summed up by Ruane (2001) when she concludes that "...it is hard to either totally prove or disprove..." (p. 12) whether linkage policies have been successful.

A more detailed example can be seen in the case of the IT sector. This is of particular importance in the Irish case, as software firms have been regularly cited by commentators within and beyond Ireland as one of the most successful examples of FDI spillovers (Andreosso-O'Callaghan and Lenihan, 2006). Buckley et al (2006) outline that the majority of foreign and domestic firms in the software industry in Ireland are located in the same region. Citing the work of Crone (2002), they outline that in excess of $70 \%$ of MNE subsidiaries and $87 \%$ of domestic firms are located in and around the greater Dublin area. They proceed to argue that such a concentration of indigenous and foreign software firms in one area is likely to facilitate increased technology transfer between the two sets of firms. Barry (1999) argued that software is an industry where one-third of all indigenous software firms have been started by ex-employees of transnationals. In a similar vein, in the case of the software industry in Ireland, evidence indicates that the vast majority of indigenous firms were founded by former employees of software and hardware transnationals (Buckley, 2005; Buckley et al., 2006). 
In explaining such 'success', Buckley et al (2006) argue that a number of factors were likely to have contributed to maximising productivity spillovers to the indigenous software industry in Ireland. These include: (1) the fact that transnationals choosing Ireland could be described as technologically superior (i.e. they employed high end technologies); (2) the transnational software sector in Ireland is almost entirely export focused; (3) former transnational employees who subsequently went on to establish their own new ventures were key knowledge transfer agents to indigenous software firms; (4) the indigenous software firms demonstrated a high absorptive capacity, e.g. via a high degree of tertiary educated employees; (5) the clustering of indigenous and transnational firms; and (6) the indigenous software sector was enhanced by Irish government policies which focused on a reorientation of the education system in the 1980s with the objective of providing a pool of graduates for technology focused industries. Point 5 in this list, the development of industry clusters, highlights a related - and to a degree a necessary precursor - to the maximization of FDI spillovers and linkages. Indeed, one of the key reasons for the promotion of cluster policy is so that firms located in particular clusters will engage in linkages and spillovers with each other.

Exactly how successful was the creation of clusters in Ireland? A focus on creating sectoral and spatial clusters in Ireland really only began in earnest in the 1980s (Buckley and Ruane, 2006). Such efforts were focused around two key high technology sectors, namely, electronics and chemicals/pharmaceuticals. More specifically, four segments of the electronics sector were targeted: microprocessors, software, computer products and printers. In line with this strategy, some of the key players in these sectors, namely Intel and Microsoft, were attracted to establish operations in Ireland (ibid.). With the location of such firms, and subsequently Hewlett Packard in printing, Ireland to all purposes had an "electronics hub" and the "spokes" were soon populated by dozens of smaller enterprises (ibid. 1620). Ireland could thus be said to have been a significant beneficiary of the formation of clusters (Krugman, 1997); with the presence of the 
above-named firms contributing to the average share of US FDI in electronics to Ireland increasing to 27 per cent between 1994 and 2001, compared to a rate of less than 12 per cent for Irish manufacturing as a whole (Buckley and Ruane, 2006). Two other key sectors where industrial clusters were created include chemicals and pharmaceuticals, with such firms clustering primarily in the Cork region of Ireland. However, in contrast to experience in the electronics sector, where production linkages between firms developed, this was not the case with the chemicals and pharmaceuticals clusters.

In general, the empirical evidence on the impact of clusters in Ireland is, however, limited, with what evidence there is suggesting that there has been relatively little sectoral clustering between transnationals and local firms, at least in low-tech sectors and manufacturing overall (Gleeson et al, 2005; Buckley and Ruane, 2006). As seen from the above discussion, there does however, appear to have been some clustering between transnationals and local firms in some high-tech sectors. As such, in concluding this brief discussion of the success or otherwise of cluster policy in Ireland (as part of our look at industrial policy more broadly), it seems that the prevailing evidence is mixed and inconclusive. The Irish government (Report of the Small Business Forum, 2006) has recognised, however, that as more low-value-added activities migrate to lower-cost countries, a greater proportion of GNP will have to be produced by indigenous firms (predominantly SMEs). Other reports commissioned by the Irish government (such as Goodbody Economic Consultants, 2002) have also focused on the importance of entrepreneurship and more specifically on eliminating the barriers to entrepreneurship in Ireland. Whilst welcoming this focus, we would argue that this should have come much earlier in Ireland's development, and we see this as an important 'lesson' for other states as they look for lessons to be learned in terms of industrial policy trajectory. 
This review only serves to reiterate our point that a holistic industrial policy needs to account for the limitations and fragilities of FDI-led growth and hence also promote measures to grow domestic capacity, and to deliver a variety of growth 'drivers' for the economy. It is fair to say that the limitations of FDI-led growth have been increasingly (if belatedly) recognised, and Ireland is now recognised to be vulnerable due to the downturn in the US economy, given its overwhelming reliance on US-based FDI. As such, at this critical period, Ireland faces increasing competition for FDI from emerging economies, and Ireland is no longer a cheap country in which to do business, due to rises in wages and raw material costs ${ }^{13}$. Whilst this has been realised, a more holistic approach to policy development at the outset could have avoided some of the problems we identified above, thereby enhancing economic development, a point which small, peripheral economies elsewhere may wish to note.

The discussion here will be incomplete without reference to the role of large indigenous firms in the development process. In many countries, such firms which are large by developing countries standards but rather 'puny' in international terms are the spearheads of spreading technical change and productivity growth. Amsden (1989) is the leading exponent of the critical role of large indigenous firms in late industrialization. What is, therefore, required in industrial policy for developing countries is the right balance between the promotion of large and small firms. To illustrate this point, Indian industrial policy in the period 1950 to 1980 is an example of a policy which encouraged small firms at the expense of large firms in order primarily to safeguard employment. Despite its good economic rationale, this policy is generally regarded as being a failure as it stopped the growth of large firms and thwarted their role in the development process. A balance or 'econo-diversity' is thus required. See further Little (1994), Ahluwalia (1992) and Singh (forthcoming).

\footnotetext{
${ }^{13}$ A related point is made by Gottheil (2003) when he argues that FDI is highly mobile and that in the case of Ireland there is also the additional threat that other countries (e.g. some of the New Member States) may also introduce low corporate taxes. He proceeds to argue that from the perspective of a potential investor that "It's the best corporate tax deal that matters" (p. 734).
} 


\section{Policy Evaluation}

In view of the types of market failures that are likely to arise in the SME sector noted above (e.g. the finance gap), one possible route to help improve the efficiency of such markets is through the services provided by industrial development agencies. The extent to which development agencies in Ireland have produced the expected effects is an issue of significant and ongoing debate. One key issue that emerged in discussions (particularly pertaining to the 1990s) is that of agency duplication of services provided. The Industrial Evaluation Unit (1999) found that around $40 \%$ of firms that received support from more than one agency availed of such support within the same time period. The prime lesson to be learned in this regard is that the support environment provided by government to firms needs to be clearly targeted and focused in its delivery. A clear underlying rationale for a specific type of intervention needs to be provided in all cases.

One of the outcomes of EU funding in the case of Ireland is that over time there was increased pressure to engage in an evaluation of industrial policies (primarily to begin with for reasons of accountability). Indeed, guidelines from the European Commission (EC) as a result of Ireland being a Structural Fund beneficiary were definitely a key driving force behind the much greater emphasis placed on evaluation in Irish policy from the early 1990s onwards (see Andreosso O' Callaghan and Lenihan, 2006). The same issues are also pertinent to small African states. A number of possible strategies can be adopted in the context of industrial policy evaluation (options 1-3 are not mutually exclusive and it needs to be stressed that a mixed approach is both possible and even desirable):

1. Wait until pressure comes from outside to evaluate. In Ireland's case this was from the EU. In the case of the African economies, the impetus may come from agencies providing ODA. This was the stance largely adopted by Ireland from around 1993 onwards. Boyle (2005) writing in the context of evaluation capacity 
development in Ireland more generally, argues a similar point when he suggests that from the perspective of developing countries that Ireland provides a key lesson in terms of monitoring and evaluation (M\&E). More specifically, he outlines that "strong external pressures linked to the availability of significant resources can be a catalyst in initiating an MNE system" (p. i). He argues that an analogy in the case of poor countries is the requirement to work on 'Poverty Reduction Strategies' with related M\&E systems, in the context of debt relief as part of the 'Highly indebted Poor Country Initiative'.

2. Familiarise themselves with 'best practice' or at least 'good practice' evaluation frameworks and methodologies adopted internationally (reflecting on the key issues learned) so that they are in a position to know 'how' to evaluate when requested to do so by external donors or organisations ;

3. View evaluation as a beneficial tool for learning. This would involve adopting a proactive approach whereby evaluation would take place at the three stages of the industrial policy process: policy formulation (ex-ante evaluation focusing on the market failure argument as a rationale for intervention and fundamental economic principles such as opportunity cost); policy implementation; and policy accountability (ex-post evaluation) (Rist 1995). Such an approach not recognises evaluation as something necessary given external pressures, but more positively sees evaluation as a worthwhile activity in terms of lessons to be learned that can subsequently be incorporated into future policy interventions. There is no doubt that many would regard evaluation as a 'luxury' in African economies where resources are already scarce. We would argue however, that if robust evaluations are carried out (which ask the right questions relating to issues such as deadweight, displacement ${ }^{14}$, multipliers and linkages) this may lead to improved future industrial policy interventions which in the long run could prove to be extremely cost effective and efficient.

We do not claim to hold Ireland up a role model in the context of industrial policy

\footnotetext{
${ }^{14}$ For a discussion of the concepts and estimation of deadweight and displacement, in the context of Ireland, see Lenihan (1999 and 2004) and Lenihan and Hart (2004).
} 
evaluation. Indeed, it hovered around option 1 for most of the 1990s, although of late, it is certainly getting nearer to option 3 . This is highlighted by Lenihan et al (2005; 14), who argue that "the methodological rigor of Irish industrial policy evaluations has been improving in recent years". It was not until some pressure came from the European Commission that Irish policy makers and academics began take industrial policy evaluation seriously. This is somewhat difficult to comprehend given that an interventionist approach to industrial policy has been a feature of the industrial policy stance by successive governments in Ireland since the 1950s, with the first grant to firms actually being awarded as far back as 1952. The degree of subsidy intervention in the Irish case is aptly summed up by Lenihan et al (2005) when they show that over the period 1980-2003, in the region of $€ 5.5$ billion was provided by the four Irish development agencies in the form of grant payments and equity investments. The key point is that any policy intervention should bring about a level of 'additionality' in excess of what would have happened if no such intervention had taken place (i.e. explore the counterfactual, which involves trying to assess what would most likely have happened if no intervention had taken place). In this regard, Storey (2000) argues that a prerequisite to any evaluation is that clear objectives be specified. More precisely, he highlights the "...impossibility of conducting an evaluation in the absence of clearly specified objectives for the policy concerned" (p. 177). This calls for a clearly defined set of policy objectives from the outset, and to allow for 'trail and error' as an important part of policy development. As UNCTAD (2007; 87) notes, referring in particular to East Asian experience:

"Indeed, the intrinsic differences among the Asian experiences underscore the importance of "trial and error" as an important ingredient of policy formulation and implementation in developmental States. This process should benefit from constant monitoring and the feeding of the lessons learnt from monitoring into new policies to overcome earlier shortcomings".

An additional challenge (as with all calls for evaluation) is who should actually 
carry out such evaluations. The follow-on question is who should evaluate the evaluators? Clearly, in the face of the level of corruption and lack of resources to carry out some evaluations in some of the African economies, this issue is particularly pertinent.

\section{Bringing in East Asian Experience}

Given some of the failures (as well as successes) of 'traditional' Japanese industrial policy (see Bailey and Sugden, 2007), some may conclude that Katz (1998) is correct in arguing that 'development state' policies should be avoided. However, in a sense economies are always in a state of 'development'; for us, the key is to adapt and tailor policies holistically to that stage of development. However, before considering the relevance of the East Asian developmental State to African countries, we need to ask: is there actually an East Asian model as such? Mainstream contributions sometimes deny the existence of such a model and argue that even if it existed, it was not very successful. Yet real-world business people have no hesitation in identifying an "Asian way of doing business" (Greenspan, 1998). In this vein, Singh (1999) suggested that there is actually general agreement on the following characteristics of the East Asian 'model':

1. A close relationship between the government and business where the government did not act without consulting business and vice versa.

2. Many interventions were carried out through a system of 'administrative guidance' rather than through formal legislation.

3. The relationship between the corporation and the financial system in countries like Japan and Korea was also very different from that of AngloSaxon capitalism. The former countries followed the so-called main bank system which involved long-term relationships between the corporations and the main banks. This enabled Japanese or Korean managers to take a long-term view in their investment decisions. The managers were not constrained by the threat of hostile take-overs on stock markets as in the 
case in the Anglo-Saxon countries, and takeover attempts were often seen as an unwelcome intrusion on the 'family way' of doing things.

4. There were differences in the internal organisation of East Asian corporations compared with those of the US and the UK. The former involved co-operative relationships between management and labour, epitomised by the system of lifetime employment. This implied considerable 'imperfections' in the labour market.

5. As for competition in product markets, such competition was not regarded by the East Asian authorities as an unalloyed good. Unlike in countries like the US, economic philosophy in the east Asian countries did not accept the dictum that 'the more competition the better'. The government in these countries were of the view that, from the perspective of promoting investment and technical change, the optimal degree of competition was not perfect or maximum competition. The governments had therefore purposefully managed and guided competition: it had been encouraged but also restricted in a number of ways.

6. East Asian governments sought not 'close' but what might be called 'strategic' integration with the world economy, i.e. they integrated up to the point where they felt it was useful for them to do so. Thus during their high-growth development phase, Japan (between 1950 and 1973) and Korea (1970s and 1980s) integrated with the world economy in relation to exports but not imports; with respect to science and technology but not finance and multi-national investment (see Chakravarty and Singh (1988).

Of course, these points represent a characterisation of the East Asian model as an 'ideal' type. Not all countries, or even Japan and Korea, have followed the model exactly at all times in the post-war period. As far as government-business relationships are concerned in reality there has been a continuum with the closest relationship to be found in Korea, and the least close in Thailand. Malaysia and Indonesia fall in between. Similarly, the main bank system worked differently in Korea compared with Japan. Unlike Japan, where the 'main banks' 
were by and large private entities, in Korea for much of the period these were directly state-controlled. Only in the recent period have they been privatised. There were also differences in approaches towards FDI and how this was used for development. Nevertheless, there is considerable truth in the view that the Asian way of doing business and the institutional structures it has generated are rather different from those of countries like the US and the UK (Greenspan, 1998; Summers, 1998).

In terms of applying this model to African countries, UNCTAD (2007B) does not see a simple replication as being very useful. However, it is nevertheless the case that East Asian countries, with the exception of Hong Kong, have at different times used a wide range of industrial policy measures with considerable success. Pulling together this variety of experiences, Chang (2006) and Lall (2006) both argue that there is indeed a strong case for the use of industrial policy but that the success of such policy critically depends on how it is designed and implemented. Drawing on their work we can highlight the following main points from East Asian experience:

1. Selectivity is important. This selection of target industries need to be realistic and related both to the country's technological capabilities and world market conditions. The success of East Asian countries "owe a lot to the fact that they did not attempt to make too big a step" (Chang, 2006; 126). Over time, technological deepening can be directly related to selective interventions (Lall, 2006).

2. Industrial policy needs to be closely integrated with an export strategy, especially in small economies. In addition, scale economies cannot be achieved without entering the export market early on. This in turn brings us back to the relevance of the Single Market for Ireland in providing a wider market. Lall (2006) argues convincingly that the success of export orientation in East Asia did not lie in 'getting prices right' and realising static comparative advantage as in the 
mainstream story, but rather enabling successful selective intervention to build new forms of dynamic comparative advantage which otherwise would not have happened, or may have taken much longer to emerge.

3. Linked to this, Lall (2006) suggests that export orientation imposed a strict discipline on industry and government in Korea and Taiwan; in Singapore this came through the need to attract, retain and upgrade FDI. More generally, the government needs to find ways to discipline the recipients of the rents it creates through the use of tariffs, subsidies etc, in order to compensate for the loss of market discipline.

4. The implementing bureaucracy needs to be both competent and politically insulated. Chang stresses that East Asian bureaucracies improved through continuous efforts over time, and not because of some unique initial endowment.

5. Close interaction between the government and private sector is necessary without the former becoming hostage to the latter. On this, Chang refers to Evans' (1995) use of the term 'embedded autonomy' to reflect the needs for both roots in society but also its own will and power. In this vein, Bailey and Sugden (2006) suggest that where Japanese industrial policy started to 'go wrong' was when it was effectively captured by giant firms for their own benefit. Recognising and avoiding such dangers seems crucial to enable policy to function for a public rather than a private benefit.

6. FDI played different roles in technology development in the East Asian 'tigers'. Those countries favouring domestic firms restricted incoming FDI, whereas those which targeted FDI sought to guide it and encourage upgrading over time. On this, Lall (2006) argues that in the longer run the only way to promote successful industrial development is through developing and diversifying local capabilities, and that whilst TNCs can assist in this they will do so only up to the point where it is profitable for them. More broadly, it is up to the government to provide the 
quasi-public goods needed for domestic capability development, upgrading and collective learning. Selectivity in FDI (as in Ireland) seems critical in making the most of FDI for broader development, both in building local capabilities and in tapping into high-tech value chains (Lall, 2006).

\section{Conclusions}

There are some noteworthy similarities and lessons to be learned (positive and negative) by the smaller African economies from both Irish and East Asian industrial policy experiences. Key amongst these is the concern expressed in this paper that industrial policy should not be seen purely in narrow terms, that is with a sole focus on attracting FDI. We argue here that there is need for a more 'holistic' approach to economic development which inter-alia focuses on the development of domestic entrepreneurship and indigenous firm expansion more generally as well as emphasising the importance of other supply side factors (e.g. infrastructure; well functioning labour markets). This more all-encompassing view of industrial policy and economic development may, it could be argued, take a longer time to materialise. This is a difficult position for the African economies to be faced with given the extremely high levels of poverty and deprivation witnessed in many of these small African economies. Such a 'holistic' growth trajectory could, however, lead to a more sustainable industrial development path, in contrast to the current situation in Ireland whereby the recent down turn in the US economy has sent shock waves through the Irish economy given its (over)dependence on US firms. ${ }^{15}$

This paper has provided some novel insights by providing a comparison between Ireland, East Asia and the small African economies. When comparisons in terms of industrial policy lessons to be learned have taken place, it tends to be solely vis-a-vis the East Asian experience (which, as seen above, undoubtedly also provides interesting economic development insights but with certain caveats).

\footnotetext{
${ }^{15}$ Even as far back as 1989, there were 307 US companies located in Ireland. By 2001, the number of US companies reached a peak at 531 (source: UNCTAD WID (2005) Country Profile Ireland and various Annual Report from IDA Ireland (various years).
} 
We suggest that another important contribution can come by looking at the Irish example, given its emphasis on corporatism rather than simply relying on state direction in the operation of industrial policy. The Irish model has some benefits in that it can also be seen as more democratic and has protected workers' rights during the development process, in contrast to the dirigisite East Asia model (what Thornton and Thornton, 2008, refer to as 'development without freedom'). In relation to the small size of the African economies, the paper recommends regional integration and sufficient ODA for infrastructural development.

Finally, we stress that some immediate actions are needed, notably with regard to the financial system in the African economies. Without such changes, a poorly functioning financial system will continue to keep investment at low levels. ${ }^{16}$ It is also important to bear in mind that the various small African economies each face their own industrial and economic development challenges, and we do not suggest a 'one size fits all' approach. As outlined by UNCTAD (2007B), referring to East-Asian experience, the path to sustainable growth and development is derived from "a pragmatic mix of markets and state action, taking into account the country-specific development challenges" (UNCTAD, 2007B; 61). It suggests that the challenge for Africa is not how to copy any model, but how to create "capitalisms" that are adaptable to the unique opportunities and development challenges in each African country (UNCTAD, 2007B). In this sense, useful lessons from elsewhere can be seen, but wholesale emulation of other models is inappropriate. As Coates $(2007 ; 193)$ concludes (when referring to Japanese experience):

"What works in one period is unlikely to work in the next; and even when it 'works', its distribution of costs and benefits is never socially equal. So when deciding which tiger to ride, it is worth remembering that the choice is only between tigers, and that if a safe ride is what you want, you would do well not to ride tigers at all".

\footnotetext{
${ }^{16}$ On the development of stock markets and banks in Africa, see further Singh (1999) and Singh (forthcoming)
} 


\section{References}

Acs Z., O'Gorman C., Szerb L. and Terjesen S. (2007) 'Could the Irish Miracle be Repeated in Hungary?' Small Business Economics, 28: 123-42.

Ahluwalia IJ (1992) Industrial Growth in India, Oxford University Press.

Amin A., \& Tomaney J. (1995) The Regional Development Potential of Inward Investment in the Less Favoured Regions of the European Community. In: Amin A. \& Tomaney J. (eds.) Behind the myth of the European Union. Routledge, London. 201-220.

Aiginger K. (2007) 'Industrial Policy: A Dying Breed or a Re-emerging Phoenix'. Journal of Industry, Competition and Trade, 7 (3/4): 297-323.

Amsden A. (1989) Asia's Next Giant: South Korea and Late Industrialization. Oxford University Press, Oxford.

Amsden A. (ed.). (1994) 'Reviews of World Bank, 1993', World Development, vol. 22 , no. 4 .

Amsden A.H. and Singh A. (1994), "The optimal degree of competition and dynamic efficiency in Japan and Korea", European Economic Review, Vol. 38, No.3/4 (April), 941-951.

Andreosso-O'Callaghan B. and Lenihan H. (2006) 'Is Ireland a Role Model for SME Development in the New Member States?' Journal of European Integration, 28 (3): 277-303.

Barry F. (ed.) (1999) Understanding Ireland's Economic Growth. Macmillan Press Ltd., Great Britain.

Barry F., Van Egeraat C. (2008) 'The Decline of the Computer Hardware Sector: How Ireland Adjusted' Quarterly Economic Commentary, Spring 2008, ESRI.

Barry F., Bradley J. and Hannan A. (2001) 'The Single Market, the Structural Funds and Ireland's Recent Economic Growth' Journal of Common Market Studies, 39 (3): 537-52.

Bailey D. (2003) FDI in Japan: An 'Open Door' or a Legacy of 'Non-Institutional' Barriers? The Journal of World Investment, 4(2).

Bailey D., de Ruyter A. and Kavanagh N. (2007) Lisbon, Sapir and Industrial Policy: Evaluating the Irish Experience, International Review of Applied Economics, Vo.21, Iss.3, 2007, 453-467.

Bailey D. and Sugden R. (2007) Kūdōka, Restructuring and Possibilities for Industrial Policy in Japan. In: D. Bailey, D. Coffey and P. Tomlinson, (eds.), Crisis or Recovery in Japan? State and Industrial Economy. Edward Elgar, Cheltenham.

Bailey D.G., Thomas R., \& Sugden R. (1998) Inward Investment in Central and Eastern Europe: the Compatibility of Objectives and the Need for an Industrial Strategy, In: M. Storper, S. Tomadakis \& L. Tsipouri (eds.) Industrial Policy for Latecomers in the Global Economy. Routledge, London. 299-322. 
Boyle R. (2005) Evaluation Capacity Development in the Republic of Ireland (ECD Working Paper Series, No 14: June). The World Bank Operations Evaluation Department, the World Bank Washington, DC.

Bradley J., Wright J. and Whelan K. (1993) Stabilization and Growth in the EC Periphery: A Study of the Irish Economy. Avebury, Aldershot.

Blomström M. \& Kokko A. (1996) Multinational Corporations and Spillovers. CEPR Discussion Paper 1365.

Blomström M., Kokko A., and Globerman S. (2000) 'The Determinants of Host Country Spillovers from Foreign Direct Investment', in Pain, N. (ed.) Inward Investment, Technological Change and Growth. 34-65.

Braunerhjelm P., Faini R., Norman V., Ruane F. \& Seabright P. (2000) Integration and the Regions of Europe: How the Right Policies can Prevent Polarisation. Centre of Economic Policy Research, London.

Brown C.J.F. (1980) Industrial Policy and Planning in Japan and France. NIESR Economic Review.

Buckley P.J., and Ruane F. (2006) 'Foreign Direct Investment in Ireland: Policy Implications for Emerging Economics' The World Economy, 29(11): 1611-1628.

Buckley R. (2005) Multinational Enterprises, Productivity Spillovers and the Growth and Development of the Irish Software Industry, unpublished PhD thesis, University of Limerick, Ireland.

Buckley R., Leddin A. and Lenihan H. (2006) "An assessment of the contribution of MNEs to the Irish Economy", ILL Foro de Economia Regional, FPRG Economico de la Rioja, Logrono, La Rioga, Spain, May $9^{\text {th }}-11^{\text {th }}$.

Chakravarty S. and Singh A. (1988) 'The Desirable Forms of Economic Openness in the South' World Institute for Development Economics Research (WIDER), Helsinki.

Coates D. (2007) The Rise and Fall of Japan as a model of 'progressive capitalism' In: D. Bailey, D. Coffey and P. Tomlinson, (eds.), Crisis or Recovery in Japan? State and Industrial Economy. Edward Elgar, Cheltenham.

Chang H-J. (2006) Industrial Policy in East Asia - Lessons for Europe, EIB Papers, 11 (2): 106-133.

Culliton J. (1992) A Time for Change: Industrial Policy for the 1990s (Report of the Industrial Policy Review Group). Stationery Office, Dublin.

European Commission (1991) The Regions in the 1990s (Fourth Periodic Report on the Social and Economic Situation in the Regions of the Community). Commission of the European Community, Brussels.

Forfás (1994) Technological Innovation in Irish Manufacturing Industry: Report for the Policy and Advisory Board for Industrial Development in Ireland by A. Fitzgerald \& M. Breathnach, Dublin.

Forfás (2004) Innovation Networks. Forfás, Dublin.

Gleeson A.M., Ruane F. and Sutherland J. (2005), Promoting Industrial Clusters: Evidence from Ireland' Institute for International Integration Studies, Discussion Paper No 89/Oct 2005. 
Global Entrepreneurship Monitor (2001) How Entrepreneurial is Ireland? The Irish Report, Fitzsimons P., O'Gorman C. \& Roche F. University College Dublin.

Goodbody Economic Consultants (2002) Entrepreneurship in Ireland. Goodbody Economic Consultants, Dublin.

Görg H. and Ruane F. (2001) 'Multinational Companies and Linkages: PanelData Evidence for the Irish Electronics Sector' International Journal of the Economics of Business, 8 (1): 1-18.

Görg H. and Ruane F. (2000) 'An Analysis of Backward Linkages in the Irish Electronics Sector' The Economic and Social Review, 31(3): 215-235.

Görg H. and Strobl E. (2002) 'Multinational Companies and Indigenous Development: An Empirical Analysis', European Economic Review, 46 (7): 1305-1322.

Görg H. and Strobl E. (2003) 'Multinational Companies, Technology Spillovers and Plant Survival', Scandinavian Journal of Economics, 105(4): 581-595.

Gottheil F. (2003) 'Ireland: What's Celtic about the Celtic Tiger?', Quarterly Review of Economics and Finance, 43: 720-734.

Greenspan A. (1998) Testimony before the Committee on Banking and Financial Service, US House of Representatives, January 30.

Heanue K. and Jacobson D. (2003) 'Low tech policy' PILOT- Newsletter 1, May, DCU Business School, Dublin City University, 9-18.

Hitchens D. and Bernie E. (1992) 'Evaluating the Culliton Report', The Irish Banking Review, Summer, 28-40.

Honohan P. and Walsh B. (2002) 'Catching up with the leaders: the Irish hare' Brookings Papers on Economic Activity, 1: 1-77.

House D. and McGrath K. (2004) 'Innovative Governance and Development in the New Ireland' Governance: An International Journal of Policy, Administration and Institutions, 17(1): 29-58.

ILO (2007) World Employment Report, Geneva, ILO.

Industrial Development Authority (IDA) Ireland Annual Reports (various years). Katz R. 1998. Japan. The System that Soured. The Rise and Fall of the Japanese Economic Miracle. M E Sharpe, London.

Kearns A. and Ruane F. (2001) 'The tangible contribution of R\&D spending foreign-owned plants to a host region: a plant level study of the Irish manufacturing sector (1980-1996)' Research Policy 30: 227-244.

Kennedy K. (2001) 'Reflections on the Process of Irish Economic Growth' Journal of the Statistical and Social Inquiry Society of Ireland, 30: 123-39.

Krugman P.R. (1997) Good News from Ireland: A Geographical Perspective, In: A.W. Gray (ed.) International Perspectives on the Irish Economy, 38-53 Indecon Economic Consultants, Dublin.

Lall S. (2005) Is African Industry Competing? QEH Working paper series No.121, Queen Elizabeth House, Oxford University.

Lall S. (2006) Industrial Policy in Developing Countries: what can we learn from East Asia? In: P. Bianchi and S. Labory, (eds.) International Handbook on Industrial Policy. Edward Elgar, Cheltenham. 
Lenihan H. and Sugden R. (2008) 'Policy on Business Networking in Ireland: A Review, and Prospects for Evaluation' in Araguren M., Iturrioz C. and Wilson J. (eds.) Networks, Governance and Economic Development: Bridging Disciplinary Frontiers. Edward Elgar, Cheltenham.

Lenihan H. (2004) 'Estimating Irish Industrial Policy in terms of deadweight and displacement: A quantitative methodological approach', Applied Economics 36(3), 229-252.

Lenihan H. and Hart M. (2004) 'The use of Counterfactual Scenarios as a means to Assess Policy Deadweight : an Irish Case Study' Environment and Planning C: Government and Policy 22(6), 817-839.

Lenihan H., Hart M. and Roper S. (2005) 'Developing an Evaluative Framework for Industrial Policy in Ireland: Fulfilling the Audit Trail or an Aid to Policy Development?' Quarterly Economic Commentary, The Economic and Social Research Institute, Ireland. Summer, June, 69-85.

Lenihan H. (1999) 'An Evaluation of Regional Development Agency's Grants in Terms of Deadweight and Displacement', Environment and Planning C: Government and Policy, 17, 303-318.

Lynch C. (2005) Can we learn from Ireland's Experience? An Irishman's Perspective, Policy Backgrounder, No.6, June 2005.

Metcalfe J. (1994) 'Evolutionary Economics and Technology Policy; Economic Journal, 104(425): 931-944, July.

Midelfart-Knarvik K.H. \& Overman H.G. (2002) Delocation and European Integration: Is Structural Spending Justified? Economic Policy, 17(35), 323359.

McAleese D. (1990) Ireland's Economic Recovery. Irish Banking Review, Summer 1990, 18-32.

McKinley T. (2005). Economic Alternatives for Sub-Saharan Africa: "Poverty Traps", MDG-based Strategies and Accelerated Capital Accumulation. UNDP draft paper for G-24 Meeting, 15-16 September 2005, New York.

Mkandawire T. (2005) Maladjusted African Economies and Globalisation. Africa Development. Vol. XXX, Nos. 1 \& 2, 2005, 1-33.

National Economic and Social Council (NESC) (2005) 'Strategy 2006: People, Productivity and Purpose' Report No. 114. December 2005. Dublin. Available at:

http://www.nesc.ie/press/press_detail.asp?newsld=82\&zoneld=4\&catld=19

Pfeffermann G. (2008) Into Africa, available at www.elmg.org/globalfocus.

Pfeffermann G. (2008) African Business Schools, available at: www.mercnetwork.org.

Pike A., Rodríguez-Pose and Tomaney J. (2006) Local and Regional Development. Routledge, London.

Rist R.C. (1995) Policy Evaluation Linking Theory to Practice. Elgar Reference Collection, Cheltenham.

Ruane F. (2001) 'Reflections on linkage policy in Irish manufacturing-policy chasing a moving target', paper presented at the UNECE/ERBD Expert Meeting on Financing for Development: Enhancing the benefits of FDI and 
improving the flow of corporate finance in transition economies, Geneva, December $3^{\text {rd }}$.

Salt J. (2005) Current Trends in International Migration in Europe, Council of Europe. CMJD. 2005.2 .

Sapir A., Aghion P., Bertola G., Hellwig M., Pisani-Ferry J., Rosati D., Viňals J. \& Wallace H. (2003) 'An Agenda for a Growing Europe: Making the EU Economic.

Schweiger C. and Wickham J. (2005) 'Is the Tiger Eating Its Children? The Two Sides Of the Irish Employment Model' Dynamics of National Employment Models (DYNAMO) Project, Country Study (Draft). http://iatinfo.iatge.de/projekt/2005/dynamo/publications.html

Singh A. (1995) The causes of Fast Economic Growth in East Asia, UNCTAD Review 1995. 91-127.

Singh A. (1997) Catching up with the West: A Perspective on Asian Economic Development into the XXI Century. Washington, DC: Inter-American Development Bank.

Singh A. (1998) Savings, Investment and the Corporation in the East Asian Miracle, Study 9, The Journal of Development Studies, vol. 34, no.6, August, 112-37.

Singh A. (1999). Asian Capitalism and the financial crisis, In: Michie J. \& GriveSmith J., Global Institutions. Routledge, London.

Singh A. and Weisse B. (1999) The Asian Model: A Crisis Foretold, International Social Science Journal No. 160.

Singh A. (forthcoming) 'The Past, Present and Future of Industrial Policy in India: Adapting to the Changing Domestic and International Environment' in M. Cimol, G. Dosi and J. Stiglitz 'Industrial Policies and Development' Oxford University Press.

Small Business Forum. (2006) Small business is big business: report of the Small Business Forum. Small Business Forum, Dublin.

Storey D. (2000) "Six Steps to Heaven: evaluating the impact of public policies to support small business in developed countries", in D.L Sexton. and H. Landström, (eds.) The Blackwell Handbook of Entrepreneurship, Blackwell, Oxford.

Summers L.H. (1998) Quoted in an article by Gaerard Baker "US looks to G7 backing on Asia Crisis" Financial Times, February 19, 1998.

The Economist (2008) 'Africa's Prospects', $11^{\text {th }}-17^{\text {th }}$ October, 33.

Thornton S.H. and W.H. Thornton (2008) Development without Freedom. The Politics of Asian Globalization. Ashgate, Aldershot.

Telesis Consultancy Group (1982) A Review of Industrial Policy, Report 64 National Economic and Social Council, Dublin.

Ugur A. and Ruane F. (2004) 'Export Platform FDI and dualistic development', Institute for International Integration Studies Discussion Paper, No 28/July 2004.

United Nations Conference on Trade and Development (UNCTAD) (2005). UNCTAD WID Country Profile Ireland. United Nations: New York. 
UNCTAD (United Nations Conference on Trade and Development) (2007a), Trade and Development Report: Regional Cooperation for Development. United Nations: New York.

UNCTAD (2007b). Economic Development in Africa: Reclaiming Policy Space. Domestic Resource Mobilization and Developmental States. United Nations, New York.

UNCTAD (United Nations Conference on Trade and Development) (2008) Trade and Development Report: Commodity Prices, Capital Flows and the Financing of Investment. United Nations, New York. 